\title{
Enhanced biosorption of metal ions from wastewater by Fenton modified Hydrilla verticillata dried biomass
}

\author{
A. Mishra • B. D. Tripathi · A. K. Rai
}

Received: 4 March 2014/Revised: 8 October 2014 / Accepted: 27 October 2014/Published online: 7 November 2014 (C) Islamic Azad University (IAU) 2014

\begin{abstract}
Present study deals with the biosorption of metal ions $\left(\mathrm{Cu}^{2+}, \mathrm{Zn}^{2+}, \mathrm{Pb}^{2+}\right.$, and $\left.\mathrm{Cd}^{2+}\right)$ from aqueous solutions as well as from wastewater using Fenton modified Hydrilla verticillata dried biomass. Fenton modification process was optimized by varying different parameters such as $\mathrm{pH}$, temperature, contact time, and $\mathrm{Fe}^{2+} / \mathrm{H}_{2} \mathrm{O}_{2}$ ratio. The modified biosorbent was characterized by using scanning electron microscopy coupled with energy-dispersive X-ray spectroscopy, Fourier transform infrared spectroscopy, and Malvern particle size analyzer. Energy-dispersive X-ray spectroscopy analysis revealed the enhancement in weight percent of $\mathrm{Cu}^{2+}(47.53 \%), \mathrm{Zn}^{2+}(41.82 \%), \mathrm{Pb}^{2+}$ $(43.76 \%)$, and $\mathrm{Cd}^{2+}(43.15 \%)$ ions on the surface of modified biosorbent after the biosorption process. The experimental data obtained from the batch study were modeled using Langmuir and Freundlich isotherm models. Experimental data showed best fitting to Freundlich isotherm model. The increase in biosorption capacity after the Fenton modification was observed, which follows the sequence: $\mathrm{Cu}^{2+}>\mathrm{Pb}^{2+}>\mathrm{Cd}^{2+}>\mathrm{Zn}^{2+}$. The biosorption process followed the pseudo-second-order kinetics, suggesting that the chemisorption may be the rate-limiting step in this study. The thermodynamic study revealed that the biosorption process was spontaneous and exothermic in nature. The biosorption capacity for multi-metal solution was found to be relatively lower than the single-metal solution. Performance of batch reactor in treating wastewater showed significant
\end{abstract}

\footnotetext{
A. Mishra

Institute of Environment and Sustainable Development, Banaras Hindu University, Varanasi 221005, India

B. D. Tripathi $(\bowtie) \cdot$ A. K. Rai

Centre of Advanced Study in Botany, Banaras Hindu University, Varanasi 221005, India

e-mail: tripathibd@gmail.com
}

increase in removal efficiency of $\mathrm{Cu}^{2+}$ (from 74 to $96 \%$ ), $\mathrm{Zn}^{2+}$ (from 67 to $84 \%$ ), $\mathrm{Pb}^{2+}$ (from 71 to $92 \%$ ), and $\mathrm{Cd}^{2+}$ (from 71 to $89 \%$ ) ions after the modification of biosorbent as compared to raw biomass.

Keywords Isotherms - Kinetics - Metal ions · Thermodynamics · Wastewater

\section{Introduction}

Contamination of surface water bodies by the discharge of untreated industrial effluents laden with toxic metals has become a very important matter of concern in the developing countries like India. Due to their persistent nature, these metals do not eliminate easily and gets accumulated in the different parts of the environment (Saygideger et al. 2005; Sasmaz and Obek 2009). Several methods are reported for the elimination of metals from wastewater such as ion exchange, chemical precipitation, solvent extraction, reverse osmosis, electrochemical treatment, membrane technologies, and flotation (Janson et al. 1982; Lundh et al. 2000; Ku and Jung 2001; Lai and Lin 2003; Cardoso et al. 2004; Medina et al. 2005; Mohsen-Nia et al. 2007; Li et al. 2008; Yuan et al. 2008). Use of these methods, however, is occasionally restricted owing to their technical or economical limitations (Puranik and Paknikar 1999). Thus, it becomes indispensable to develop simple, cost-effective, and environment-friendly technique for the removal of metal ions from wastewater. Recently, removal of metal ions using biosorption technique has gained significant interest because of their high effectiveness, low cost, and simplicity (Vijayaraghavan et al. 2006; Dekhil et al. 2011; Santos et al. 2011; Ekmekyapar et al. 2012; Mane and Bhosle 2012; Zan et al. 2012; Deng et al. 2013; Bhatti and 
Hamid 2014). To augment the biosorption capacity and to reduce organic contents of low-cost natural biosorbents, different modification techniques have been utilized by previous researchers (Argun and Dursun 2008; Fatima et al. 2013). Among them, the Fenton's oxidation process has attracted considerable interest. Fenton's reagent is a mixture of ferrous iron and hydrogen peroxide $\left(\mathrm{Fe}^{2+} / \mathrm{H}_{2} \mathrm{O}_{2}\right)$, which generates highly reactive hydroxyl radical, capable of degrading a wide range of organic and inorganic pollutants (San Sebastian et al. 2003; Pignatello et al. 2006). In addition to this, Fenton process has numerous significant advantages; for instance, reagents are inexpensive, short reaction time among all advanced oxidation processes (Pouran et al. 2013), iron is highly abundant, hydrogen peroxide is easy to handle and environmentally benign (Munter 2001; Venny et al. 2012), high efficiency of mineralization facilitates the conversion of organic pollutants into non-toxic carbon dioxide (Nidheesh et al. 2013), and the overall procedure is easy to execute and control (Argun and Dursun 2008; Miretzky and Munoz 2011). Hydrogen peroxide used in the Fenton process would cause no environmental or ecological threat because diluted and stabilized hydrogen peroxide (5-20\%) was applied, which not only promotes a safer working environment during exothermic in situ application of Fenton reaction, but also results in enhanced treatment efficiency throughout the in situ remediation compared to concentrated $\mathrm{H}_{2} \mathrm{O}_{2}$ (30-35\% commercial grade), as already reported elsewhere (Kakarla et al. 2002; Venny et al. 2012).

It is very well documented that both living or dead aquatic plants are hyper-accumulators of metals (Singh et al. 2011; Li et al. 2013). Therefore, the application of these aquatic plants for metal removal from wastewater has gained considerable interest. Since Hydrilla verticillata is a submerged invasive aquatic plant that interferes with navigation, irrigation, recreation, and power generation, it could be interesting to reinforce its use as biosorbent as a strategy to control invasion episodes. Therefore, in the present research work, $H$. verticillata plant was selected for the study because of its wide spread availability throughout the year and very fast growth rate $(2.5 \mathrm{~cm}$ per day; Nigam et al. 2013). Various literatures on biosorption of different metals utilizing $H$. verticillata as biosorbent suggest that these aquatic plants possess hydroxyl groups in their cellulosic matrix (Huang et al. 2010; Li et al. 2013; Naveen et al. 2011). Modification or pre-treatment of biosorbent using Fenton's reagent technique can be used to oxidize these hydroxyl groups of cellulose into carboxyl groups by creating a weak cationic ion exchanger (Shukla and Pai 2005), which ultimately could enhance the metal removal efficiency up to many folds as compared to the other previous research studies (Nasernejad et al. 2005; Kumar et al. 2007; Li et al. 2007; Singh et al. 2007; King et al. 2008;
Mohammadi et al. 2010; Liang et al. 2011; Momcilovic et al. 2011; Tay et al. 2011; Zhang 2011; Verma et al. 2013; Kumar 2014; Tasar et al. 2014) without imposing much burden on the economy. Furthermore, the use of Fenton modified dried biomass of $H$. verticillata $(\mathrm{FMDBH})$ for the removal of metal ions from aqueous solution and their application for treating wastewater does not exist. Therefore, the aim of the present research study was to investigate the potential of FMDBH in removing metal ions $\left(\mathrm{Cu}^{2+}\right.$, $\mathrm{Zn}^{2+}, \mathrm{Pb}^{2+}$, and $\mathrm{Cd}^{2+}$ ) from aqueous solutions as well as from wastewater. Various mathematical models related to biosorption isotherm, kinetics, and thermodynamic parameters were utilized for the better perception of the overall biosorption process. Moreover, these models were also used to compare the biosorption capacity of FMDBH with nonmodified/raw $H$. verticillata dried biomass (RB). Batch experiments for the present study were performed at Pollution Ecology Research Laboratory (PERL), Centre of Advanced Study in Botany, Banaras Hindu University, Varanasi, India, from July 2013 to January 2014.

\section{Materials and methods}

Wastewater sample collection and analysis

Representative wastewater samples were collected from the effluent channel of Bhagwanpur sewage treatment plant, Varanasi, India, in polytetrafluoroethylene (PTFE) bottles (pre-washed with acid), preserved and transported to the laboratory in ice boxes. Concentration of metal ions in samples (Table 1) was analyzed by using standard protocols (APHA 2012).

\section{Biosorbent preparation}

The live biomass of $H$. verticillata was collected from the Agro-farm pond of the Banaras Hindu University, Varanasi, India. The biomass was washed under the running tap water followed by ultrapure water (Milli-Q) several times

Table 1 Concentration of $\mathrm{Cu}^{2+}, \mathrm{Zn}^{2+}, \mathrm{Pb}^{2+}$, and $\mathrm{Cd}^{2+}$ in wastewater samples with their maximum effluent discharge standards

\begin{tabular}{|c|c|c|c|}
\hline $\begin{array}{l}\text { Metal } \\
\text { ions }\end{array}$ & $\begin{array}{l}\text { Concentration in } \\
\text { wastewater samples } \\
\left(\mathrm{mg} \mathrm{L}^{-1}\right)\end{array}$ & $\begin{array}{l}{ }^{\mathrm{A}} \text { EPA (2004) } \\
\left(\mathrm{mg} \mathrm{L}^{-1}\right)\end{array}$ & $\begin{array}{l}{ }^{\mathrm{B}} \text { BIS specification } \\
\text { IS } 10500 \\
\left(\mathrm{mg} \mathrm{L}^{-1}\right)\end{array}$ \\
\hline $\mathrm{Cu}^{2+}$ & 4.64 & 0.25 & 3.00 \\
\hline $\mathrm{Zn}^{2+}$ & 3.75 & 1.00 & 5.00 \\
\hline $\mathrm{Pb}^{2+}$ & 1.34 & - & 0.10 \\
\hline $\mathrm{Cd}^{2+}$ & 3.28 & 0.01 & 2.00 \\
\hline
\end{tabular}

${ }^{a}$ EPA (Environmental Protection Agency) (2004), USA

b BIS (Bureau of Indian Standard Specification), IS 10500 (1993), India 
to remove dust particles adhered to its surface, dried in sunlight for 2 days followed by oven drying at $70{ }^{\circ} \mathrm{C}$ for $48 \mathrm{~h}$. After drying, the biomass was crushed and sieved through mesh to get particles below 1 millimeter in size. The dried biomass of $H$. verticillata (biosorbent) was further subjected to Fenton modification process.

Fenton modification of biosorbent

Fenton modification of dried biomass was carried out by the method as illustrated elsewhere (Argun and Dursun 2008). After determining the optimum $\mathrm{Fe}^{2+} / \mathrm{H}_{2} \mathrm{O}_{2}$ ratio, $\mathrm{pH}$, temperature, and contact time, $20 \mathrm{mg}$ of dried biomass of $H$. verticillata was added into 500-ml Erlenmeyer flask containing $250 \mathrm{ml}$ Fenton's reagents and agitated on rotatory shaker at $250 \mathrm{rpm}$ for $60 \mathrm{~min}$. After agitation, the solution was filtered and the dried biomass was washed with ultrapure water followed by oven drying at $80{ }^{\circ} \mathrm{C}$ for $2 \mathrm{~h}$.

Metal solutions

Analytical reagent grade chemicals were used in the present research study. Metal stock solutions $\left(1,000 \mathrm{mg} \mathrm{L}^{-1}\right)$ of $\mathrm{Cu}^{2+}, \mathrm{Zn}^{2+}, \mathrm{Pb}^{2+}$, and $\mathrm{Cd}^{2+}$ were prepared by dissolving known quantity of $\mathrm{Cu}\left(\mathrm{NO}_{3}\right) \cdot 2 \cdot 5 \mathrm{H}_{2} \mathrm{O}, \mathrm{ZnSO}_{4} \cdot 7 \mathrm{H}_{2} \mathrm{O}$, $\mathrm{PbNO}_{3}$, and $\mathrm{CdCl}_{2} \cdot 0.5 \mathrm{H}_{2} \mathrm{O}$, respectively, in ultrapure Milli-Q water. Standard solutions of different concentrations were finally prepared by diluting the stock solutions. $0.1 \mathrm{M} \mathrm{NaOH}$ and $\mathrm{HNO}_{3}$ were used for the $\mathrm{pH}$ adjustment.

\section{Characterization of FMDBH}

\section{Fourier transform infrared spectroscopy (FT-IR)}

The FT-IR spectra of RB, FMDBH before and after biosorption were obtained using PerkinElmer Spectrum version 10.03.05 to determine the alteration in peaks of functional groups of the biosorbent.

\section{Scanning electron microscopy (SEM)-energy-dispersive} $X$-ray spectroscopy $(E D X)$ analysis

The alteration in surface morphology and elemental composition of FMDBH before and after the biosorption process was analyzed by using SEM coupled with EDX (FEI QUANTA 200 F).

Experimental design

\section{Biosorption batch experiment}

Biosorption batch experiments were performed in Erlenmeyer flask previously cleaned with dilute nitric acid, containing $250 \mathrm{ml}$ solution of metal ions at the desired $\mathrm{pH}$ of $5.250 \mathrm{mg}$ of RB and FMDBH was then added to the flask separately and agitated at $250 \mathrm{rpm}$ for $60 \mathrm{~min}$. After agitation, the solution was centrifuged at 2,000 rpm for $10 \mathrm{~min}$ and finally filtered by cellulose acetate membrane $(0.45 \mu \mathrm{m})$. Atomic absorption spectrophotometer was employed for the measurement of initial and final metal ions concentration. All the batch experiments including the effect of $\mathrm{pH}$, initial metal ion concentration, and contact time on biosorption were performed in triplicate to avoid errors in measurement, and the results were reported as the mean values of replicates in the subsequent sections. The standard deviation from the means of all batch experiments was within $3 \%$. Hence, mean values were presented along with the error bars of $\pm 3 \%$ in the graphs, all through the manuscript. Under the similar experimental conditions, metal ions-free and dried biomass-free blanks were also carried out as controls. The quantity of metal ion biosorbed onto raw biomass (RB) and Fenton modified dried biomass of $H$. verticillata (FMDBH) was calculated by using subsequent mass balance expression (Davis et al. 2000):

$Q_{\mathrm{MA}}=\frac{V_{\mathrm{s}}\left(C_{i}-C_{f}\right)}{W_{\mathrm{DB}}}$

where $Q_{\mathrm{MA}}$ is the quantity of metal biosorbed $\left(\mathrm{mg} \mathrm{g}^{-1}\right), V_{\mathrm{S}}$ is the volume of solution (L), $C_{\mathbf{i}}$ and $C_{\mathrm{f}}$ are initial and final metal ion concentration $\left(\mathrm{mg} \mathrm{L}^{-1}\right)$, and $W_{\mathrm{DB}}$ is the weight of dried biomass $(\mathrm{g})$. The removal efficiency of metals $\left(R E_{\mathrm{M}}\right)$ onto $\mathrm{RB}$ and $\mathrm{FMDBH}$ was calculated by using the following equation (Miretzky and Munoz 2011):

$R E_{\mathrm{M}}=\frac{\left(C_{\mathrm{i}}-C_{\mathrm{f}}\right)}{C_{\mathrm{f}}} \times 100$

Performance of batch reactor in treating secondary effluent

Performance of batch reactor in treating secondary effluent containing metal ions collected from the effluent channel of Bhagwanpur sewage treatment plant was assessed by utilizing wastewater samples instead of metal solutions under same experimental conditions.

\section{Results and discussion}

Characterization of biosorbent

The average particle size of the RB and FMDBH was analyzed using Malvern Matersizer 2000. The FT-IR spectral characteristics of RB, FMDBH before and after biosorption are given in Fig. 1. After Fenton modification of biomass and biosorption process, shift in different peaks was observed, suggesting the combination of functional groups and metal ions (Baral et al. 2009; Huang et al. 
Fig. 1 FT-IR spectra of $a$ RB $b$ FMDBH before biosorption $c$ FMDBH after biosorption

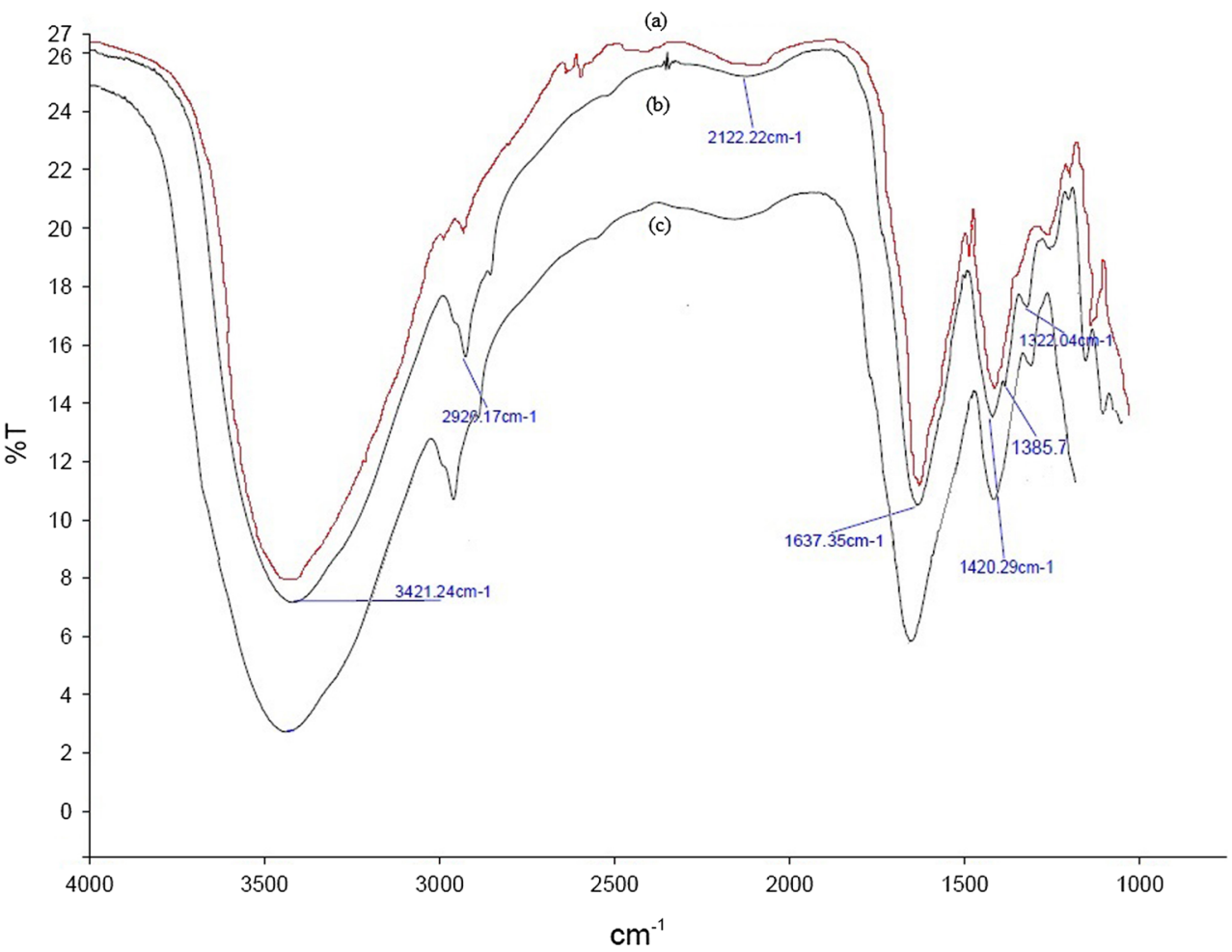

2010). SEM images of FMDBH are shown in Fig. 2a, b. It can be observed from the figures that the surface was rough before biosorption process, which becomes smooth after the process. EDX images of FMDBH before and after biosorption are given in Fig. 2a, b. The weight percent of the $\mathrm{Cu}^{2+}, \mathrm{Zn}^{2+}, \mathrm{Pb}^{2+}$, and $\mathrm{Cd}^{2+}$ ions on the surface of Fenton modified biosorbent before biosorption were observed to be $0.41,0.43,0.38$, and $0.35 \%$, respectively. But after the process of biosorption, significant increase in the weight percent of $\mathrm{Cu}^{2+}(47.53 \%), \mathrm{Zn}^{2+}(41.82 \%)$, $\mathrm{Pb}^{2+}(43.76 \%)$, and $\mathrm{Cd}^{2+}(43.15 \%)$ ions was observed. This clearly confirms the biosorption of metal ions on the surface of FMDBH. Moreover, the reduction in the peaks of potassium and sodium suggests (Fig. 2a, b) that there might be the involvement of an ion-exchange mechanism in the process (Huang et al. 2010).

Effect of Fenton oxidation process parameters on modification of biosorbent

The effectiveness of the overall Fenton oxidation process in terms of hydroxyl radical formation and utilization is governed by process parameters, viz., $\mathrm{pH}$, temperature, $\mathrm{Fe}^{2+} / \mathrm{H}_{2} \mathrm{O}_{2}$ ratio, and contact. Therefore, it becomes necessary to optimize these parameters. For the modification process, the removal of $\mathrm{Cu}^{2+}$ ions was considered and results were applied in all the following batch experiments. The effect of $\mathrm{pH}$ on the Fenton modification of $H$. verticillata dried biomass was evaluated by the efficiency of $\mathrm{Cu}^{2+}$ removal (Fig. 3a). The maximum biosorption of metal ion was achieved at $\mathrm{pH}$ value 3.5 (Fig. 3a). At $\mathrm{pH}$ values $<3.5$, the excess production of $\mathrm{H}^{+}$ion suppresses the hydroxyl radical formation. On the other hand, generation of metal hydroxides at $\mathrm{pH}$ values $>4$ hinders the whole catalytic process suppressing the formation of hydroxyl radical (Miretzky and Munoz 2011). Thus, it can be concluded that for the modification of biosorbent, the optimum $\mathrm{pH}$ value was 3.5 . Since there was no significant effect on the biosorption of metal ions with rise in temperature from 20 to $70{ }^{\circ} \mathrm{C}$ (Fig. 3b), therefore room temperature was selected as an optimum temperature for the modification process. The optimum biosorbent dose for modification process was observed to be $80 \mathrm{~g} \mathrm{~L}^{-1}$ (Fig. 3c). Also, $\mathrm{Fe}^{2+} / \mathrm{H}_{2} \mathrm{O}_{2}$ ratio of 0.01 (w/w) was found to be optimum for the process. Figure $3 d$ suggests that 60-min contact time was optimum for the modification reaction.

\section{Biosorption batch studies}

\section{Effect of initial metal solution $\mathrm{pH}$ on biosorption}

Earlier studies have shown that the $\mathrm{pH}$ of the metal solution greatly influences the metal ion solubility, counter ion concentration present on the biosorbent surface, and the extent of ionization of biosorbate (Gupta 
Fig. 2 SEM-EDX image of FMDBH a before biosorption b after biosorption

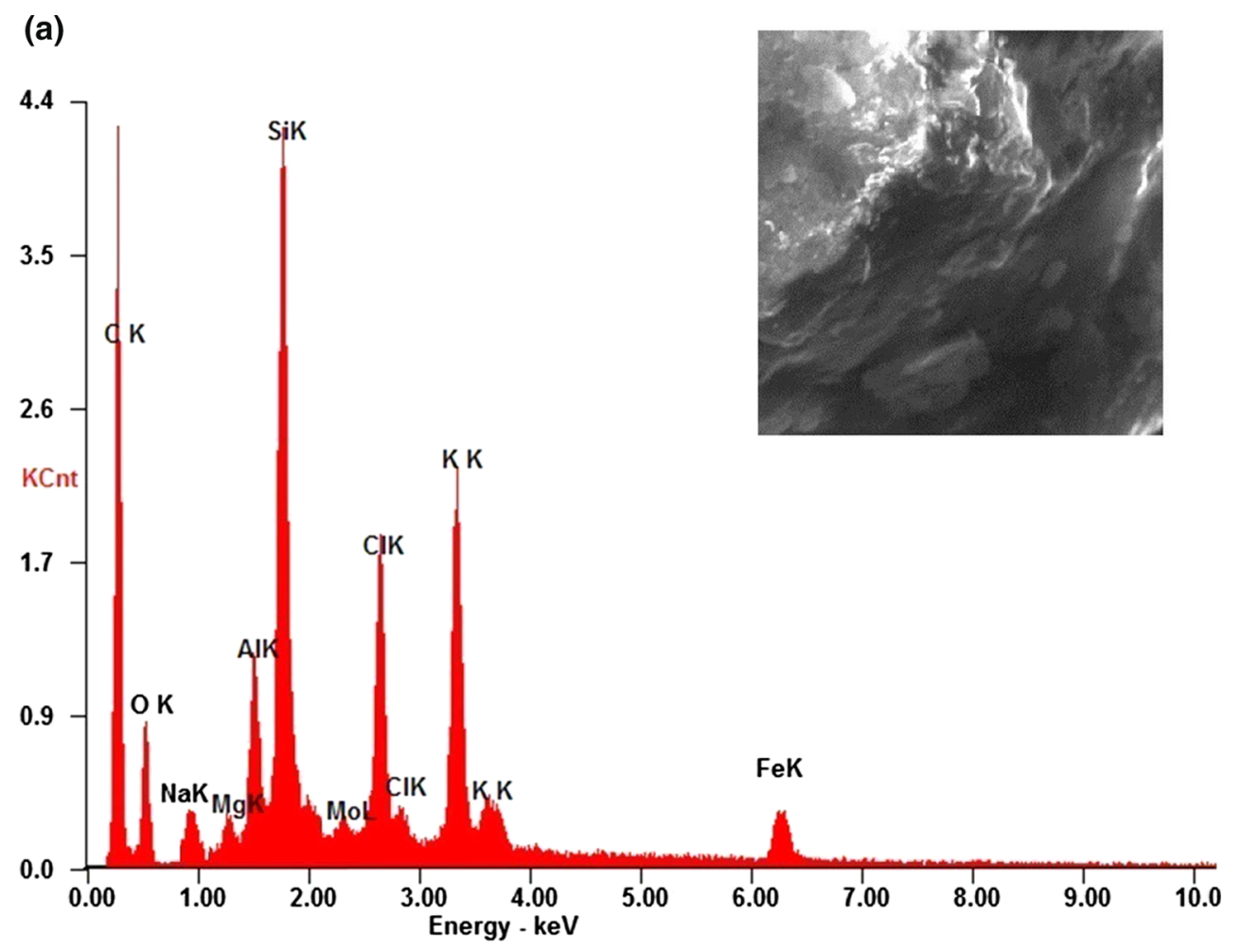

(b)

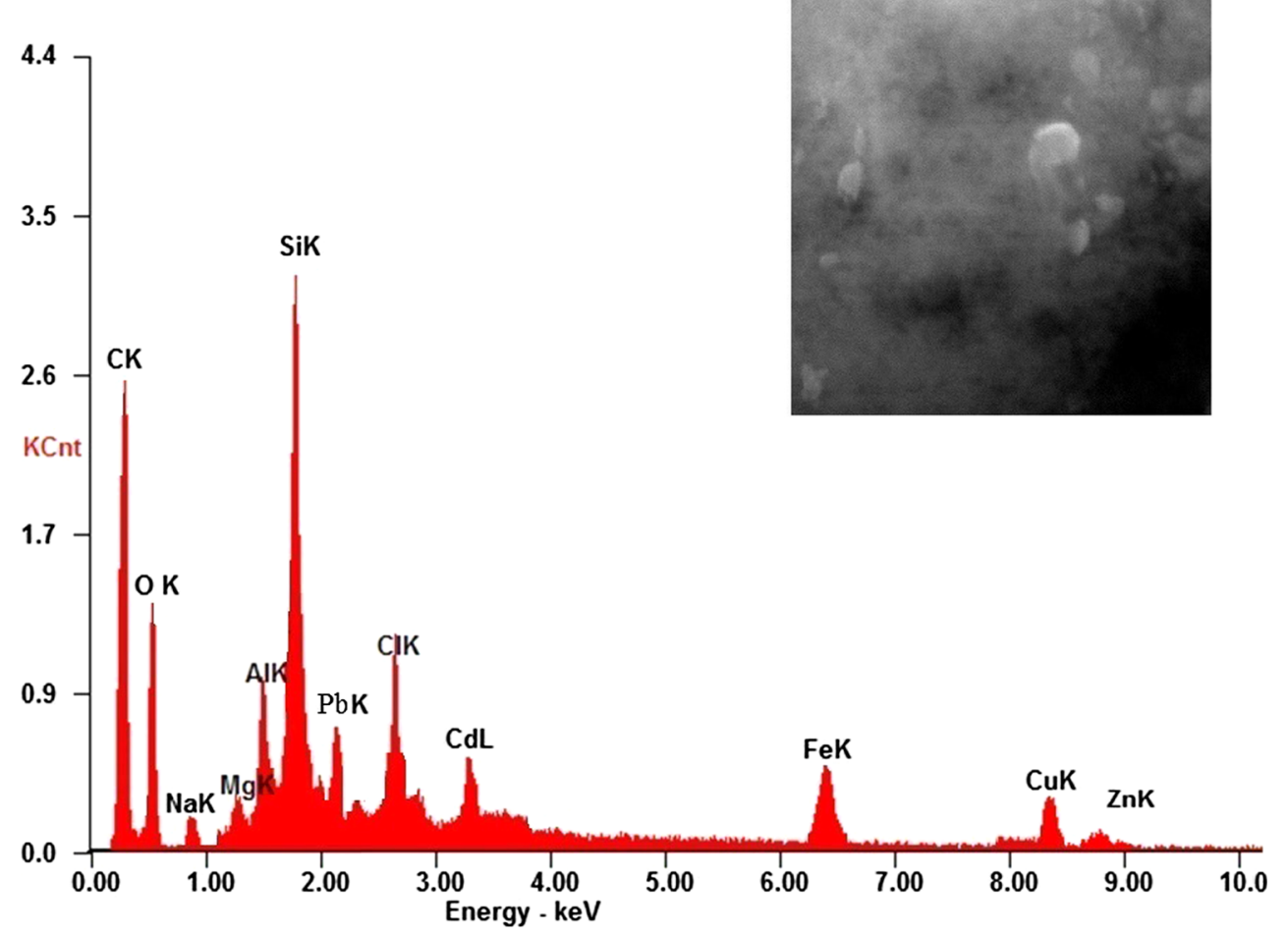

et al. 2010). Thus, the effect of initial metal solution $\mathrm{pH}$ on the biosorption process using RB and FMDBH was studied. In order to examine the effect, the $\mathrm{pH}$ range was varied from 1 to 7 . For RB, the optimum $\mathrm{pH}$ value was found to be 5.2 for $\mathrm{Cu}^{2+}, 4.5$ for $\mathrm{Zn}^{2+}, 5.0$ for $\mathrm{Pb}^{2+}$, and 6.0 for $\mathrm{Cd}^{2+}$, whereas the optimum biosorption capacity 
Fig. 3 Effect of a $\mathrm{pH}$

b temperature $\mathbf{c}$ dose $\mathbf{d}$ contact time on the Fenton modification process
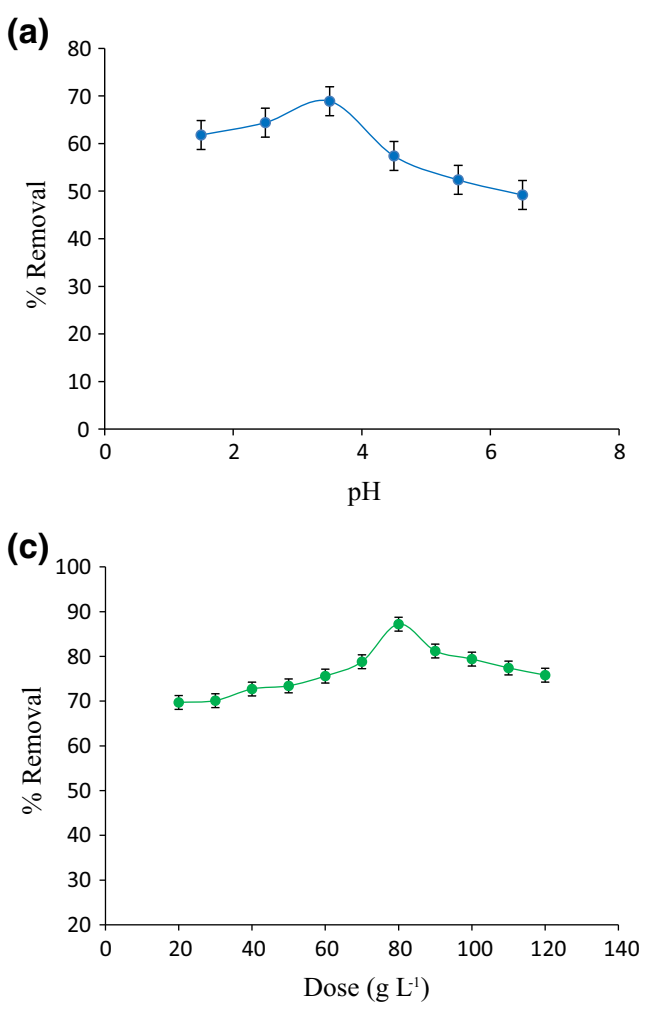

(b)

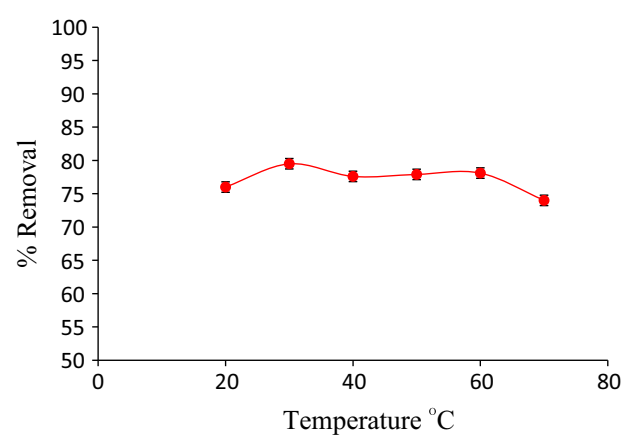

(d)

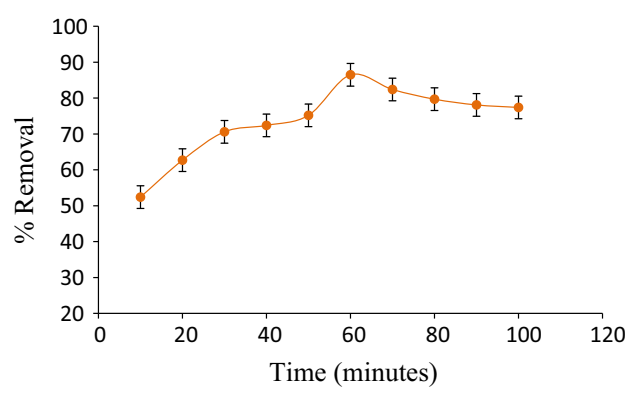

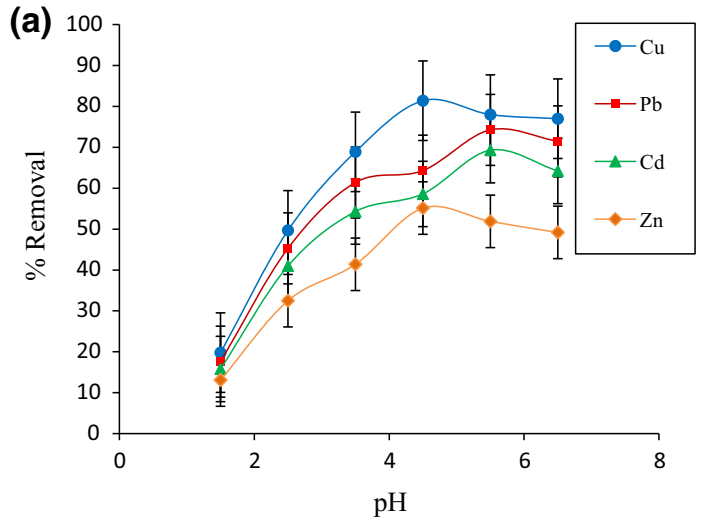

(c)

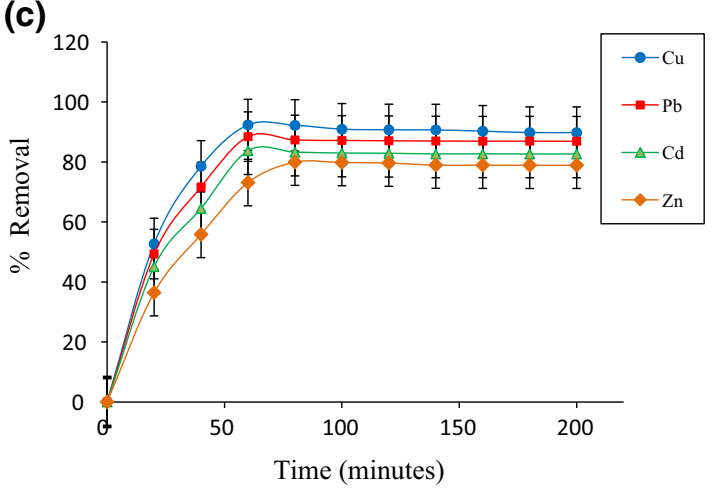

(b)

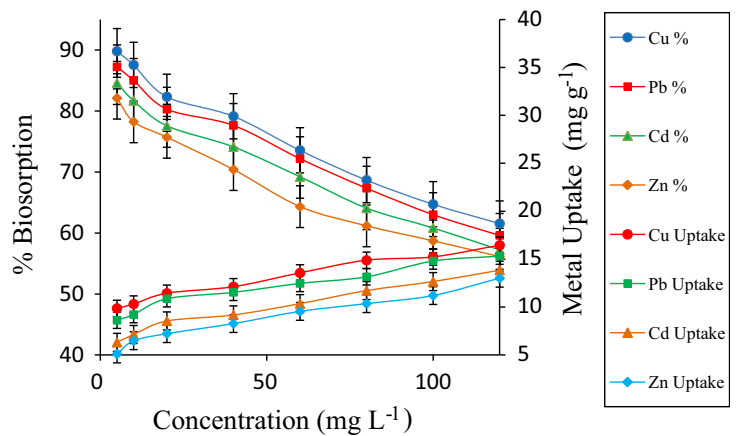

(d)

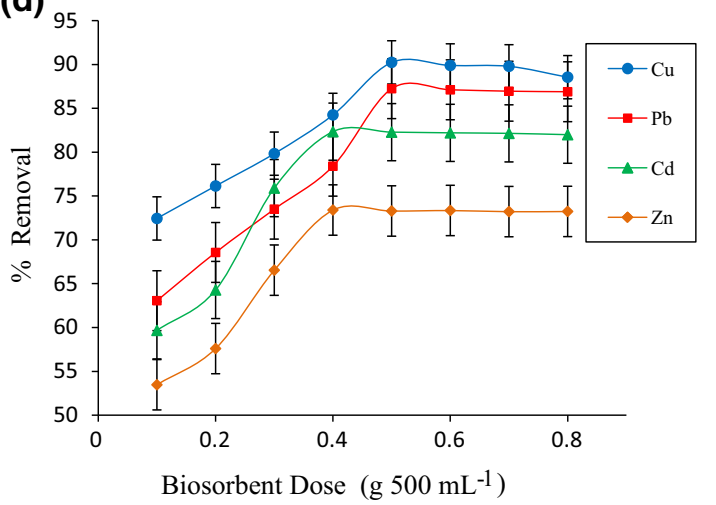

Fig. 4 Effect of a pH b initial metal ion concentration $\mathbf{c}$ time $\mathbf{d}$ biosorbent dose on the removal of metal ions using FMDBH 
of metals using FMDBH was observed at $\mathrm{pH}$ value 4.5 for $\mathrm{Cu}^{2+}$ and $\mathrm{Zn}^{2+}$ and $\mathrm{pH} 5.5$ for $\mathrm{Pb}^{2+}$ and $\mathrm{Cd}^{2+}$ (Fig. 4a). Sharp decrease in biosorption capacity was observed below pH 2.5. This might be because of the development of repulsive force due to the protonation of active binding sites which restricts the binding of metal ions under acidic condition (Aldor et al. 1995; Gupta et al. 2000; Hawari and Mulligan 2006). Similarly, formation of metal hydroxides at $\mathrm{pH}$ values above neutral results in the precipitation of metal ions from the solution, thereby decreasing the overall biosorption capacity (Hawari and Mulligan 2006; Gupta et al. 2010).

\section{Effect of initial metal ion concentration on biosorption}

The efficiency of $\mathrm{Cu}^{2+}, \mathrm{Zn}^{2+}, \mathrm{Pb}^{2+}$, and $\mathrm{Cd}^{2+}$ biosorption by $\mathrm{FMDBH}$ at different concentrations was examined at the most suitable experimental conditions. The results are shown in Fig. 4b. From figure, it is clear that as the metal concentration increases, $\mathrm{Cu}^{2+}, \mathrm{Zn}^{2+}, \mathrm{Pb}^{2+}$, and $\mathrm{Cd}^{2+}$ uptake by FMDBH increases from 9.86 to $16.45 \mathrm{mg} \mathrm{g}^{-1}$, 8.63 to $15.32 \mathrm{mg} \mathrm{g}^{-1}, 6.32$ to $13.85 \mathrm{mg} \mathrm{g}^{-1}$, and 5.11 to $13.01 \mathrm{mg} \mathrm{g}^{-1}$, respectively, but the biosorption percentage of $\mathrm{Cu}^{2+}, \mathrm{Zn}^{2+}, \mathrm{Pb}^{2+}$, and $\mathrm{Cd}^{2+}$ ions decreases from 89.81 to $61.55 \%, 87.23$ to $59.60 \%, 84.62$ to $57.24 \%$, and 82.11 to $56.12 \%$, respectively. The increase in metal uptake could be attributed to the differences in concentration gradient across the two phases. Decrease in biosorption percentage might be due to the lack of availability of more active sites and sufficient surface area to hold more metal ions present in the solution (Kumar et al. 2006; Gupta et al. 2010). Similarly, the effect of initial metal ion concentration on biosorption of $\mathrm{Cu}^{2+}, \mathrm{Zn}^{2+}, \mathrm{Pb}^{2+}$, and $\mathrm{Cd}^{2+}$ using $\mathrm{RB}$ showed the similar trend but is less efficient as compared to FMDBH.

\section{Effect of contact time on biosorption}

The effect of contact time on the biosorption of $\mathrm{Cu}^{2+}$, $\mathrm{Zn}^{2+}, \mathrm{Pb}^{2+}$, and $\mathrm{Cd}^{2+}$ ions using FMDBH is presented in Fig. 4c. Throughout the experiment, the other parameters, viz., $\mathrm{pH}(4.5$ and 5.5$)$, temperature $\left(30^{\circ} \mathrm{C}\right)$, initial metal concentration $\left(10 \mathrm{mg} \mathrm{L}^{-1}\right)$, and biosorbent dose $(0.5 \mathrm{~g}$

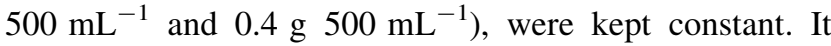
can be concluded from the figure that the biosorption process was very fast initially for a period of $20 \mathrm{~min}$ thereafter the process becomes slow and reached the equilibrium at $60 \mathrm{~min}$ (for $\mathrm{Cu}^{2+}, \mathrm{Pd}^{2+}$, and $\mathrm{Cd}^{2+}$ removal) and $80 \mathrm{~min}$ (for $\mathrm{Zn}^{2+}$ removal) using FMDBH. Very fast process of biosorption initially could be attributed to the availability of more free surface active sites. Once these sites are blocked, the intra-particle diffusion of biosorbate takes place, which might be responsible for the slower biosorption process at the later stage (Baral et al. 2009). For biosorption using RB, the optimum contact time was found to be $80 \mathrm{~min}$ for $\mathrm{Cu}^{2+}$ removal, $90 \mathrm{~min}$ for $\mathrm{Pb}^{2+}$ and $\mathrm{Cd}^{2+}$ removal, and $120 \mathrm{~min}$ for $\mathrm{Zn}^{2+}$ removal.

\section{Effect of biosorbent dose}

The effect of varying biosorbent dosage on the removal efficiency of $\mathrm{Cu}^{2+}, \mathrm{Zn}^{2+}, \mathrm{Pb}^{2+}$, and $\mathrm{Cd}^{2+}$ using $\mathrm{FMDBH}$ is shown in Fig. 4d. The percentage of metal removal increased from 72.44 to $90.24 \%$ for $\mathrm{Cu}^{2+}$, from 63.06 to $87.24 \%$ for $\mathrm{Pb}^{2+}$, from 59.67 to $82.34 \%$ for $\mathrm{Cd}^{2+}$, and from 53.47 to $73.40 \%$ for $\mathrm{Zn}^{2+}$ with increase in biosorbent dose from 0.1 to $0.8 \mathrm{~g} 500 \mathrm{~mL}^{-1}$ with adsorbate concentration of $10 \mathrm{mg} \mathrm{L}^{-1}$. The increase in biosorption of metal ions with increasing biosorbent dosage can be attributed to the rise in overall surface area due to increase in more active sites on the biosorbent. The optimum biosorbent

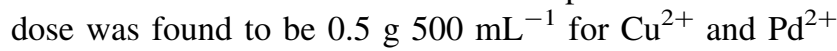

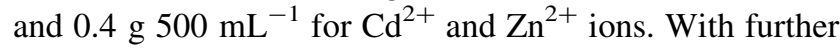
increase in biosorbent dose beyond the optimum level, the removal efficiency of metal ions remained almost constant, this may be due to the reaching of equilibrium state at given experimental conditions (Baral et al. 2009). Likewise, for RB, the optimum biosorbent dose was found to be $0.7 \mathrm{~g} 500 \mathrm{~mL}^{-1}$ for $\mathrm{Cu}^{2+}$ and $\mathrm{Zn}^{2+}$ ions and $0.5 \mathrm{~g}$ $500 \mathrm{~mL}^{-1}$ for $\mathrm{Pd}^{2+}$ and $\mathrm{Cd}^{2+}$ ions.

\section{Effect of particle size}

Particle size is one of the main parameters which influence the biosorption capacity. The effect of varying average particle size of RB and FMDBH on biosorption was studied with three different particle sizes (100, 250, and $500 \mu \mathrm{m})$, keeping other parameters constant. For FMDBH, the amount of metal ion biosorbed at equilibrium increased from 11.42 to $19.67 \mathrm{mg} \mathrm{g}^{-1}, 7.84$ to $12.14 \mathrm{mg} \mathrm{g}^{-1}, \quad 9.55$ to $15.90 \mathrm{mg} \mathrm{g}^{-1}$, and 8.26 to $15.22 \mathrm{mg} \mathrm{g}^{-1}$ for $\mathrm{Cu}^{2+}, \mathrm{Zn}^{2+}, \mathrm{Pb}^{2+}$, and $\mathrm{Cd}^{2+}$ ions, respectively, with decrease in particle size from $500 \mu \mathrm{m}$ to $100 \mu \mathrm{m}$. Similarly, for RB, the metal uptake increases with decrease in particle size $\left(8.34\right.$ to $10.63 \mathrm{mg} \mathrm{g}^{-1}$ for $\mathrm{Cu}^{2+}, 5.38$ to $8.66 \mathrm{mg} \mathrm{g}^{-1}$ for $\mathrm{Zn}^{2+}, 5.25$ to $8.52 \mathrm{mg} \mathrm{g}^{-1}$ for $\mathrm{Pb}^{2+}, 7.16$ to $10.88 \mathrm{mg} \mathrm{g}^{-1}$ for $\mathrm{Cd}^{2+}$ ). Similar behavior was also reported by other researchers for different metals using powdered stem of Arundo donax (Song et al. 2014), dried prickly pear cactus (Opuntia ficus indica) cladodes (Barka et al. 2013), pine cone shell (Blazquez et al. 2012), defatted Carica papaya seeds (Gilbert et al. 2011). 
Table 2 Langmuir and Freundlich isotherm constants and correlation coefficients of isotherm models

\begin{tabular}{|c|c|c|c|c|c|c|c|}
\hline \multirow[t]{2}{*}{ Metal ions } & \multirow[t]{2}{*}{ Treatment } & \multicolumn{3}{|c|}{ Langmuir } & \multicolumn{3}{|c|}{ Freundlich } \\
\hline & & $\mathrm{Q}_{\max }$ & $b$ & $\mathrm{R}^{2}$ & $\mathrm{~K}_{\mathrm{f}}$ & $1 / n$ & $\mathrm{R}^{2}$ \\
\hline \multirow[t]{2}{*}{$\mathrm{Cu}^{2+}$} & Raw biomass & 27.86 & 0.108 & 0.896 & 18.35 & 0.624 & 0.922 \\
\hline & Fenton modified biomass & 106.23 & 0.459 & 0.996 & 22.16 & 0.964 & 0.999 \\
\hline \multirow[t]{2}{*}{$\mathrm{Zn}^{2+}$} & Raw biomass & 50.66 & 0.156 & 0.858 & 14.76 & 0.523 & 0.879 \\
\hline & Fenton modified biomass & 109.32 & 0.521 & 0.982 & 19.75 & 0.826 & 0.989 \\
\hline \multirow[t]{2}{*}{$\mathrm{Pb}^{2+}$} & Raw biomass & 32.14 & 0.122 & 0.877 & 17.13 & 0.573 & 0.903 \\
\hline & Fenton modified biomass & 108.56 & 0.498 & 0.992 & 21.47 & 0.949 & 0.996 \\
\hline \multirow[t]{2}{*}{$\mathrm{Cd}^{2+}$} & Raw biomass & 40.43 & 0.135 & 0.865 & 15.91 & 0.556 & 0.894 \\
\hline & Fenton modified biomass & 110.78 & 0.566 & 0.988 & 20.33 & 0.872 & 0.995 \\
\hline
\end{tabular}

Biosorption isotherm studies

\section{Single-component system}

The equilibrium biosorption data obtained from the batch study were modeled using Langmuir (Langmuir 1916) and Freundlich (Freundlich 1906) isotherm model. Langmuir model is expressed by equation as follows:

$Q_{\mathrm{e}}=\frac{Q_{\max } \times b \times C_{\mathrm{e}}}{1+b \times C_{\mathrm{e}}}$

where $Q_{\mathrm{e}}$ is the amount of metal ions biosorbed $\left(\mathrm{mg} \mathrm{g}^{-1}\right)$, $Q_{\max }$ is the maximum biosorption capacity $\left(\mathrm{mg} \mathrm{g}^{-1}\right), C_{\mathrm{e}}$ is the metal ions concentration in the solution at equilibrium $\left(\mathrm{mg} \mathrm{L}^{-1}\right)$, and $b$ is the constant related to the energy or net enthalpy of biosorption $\left(\mathrm{L} \mathrm{mg}^{-1}\right)$. In order to fit the experimental data, the linear form of Langmuir expression was used, which is described by the equation given as follows:

$\frac{1}{Q_{\mathrm{e}}}=\frac{1}{Q_{\max }}+\frac{1}{Q_{\max } \times b} \times \frac{1}{C_{e}}$

The Langmuir isotherm fitting parameters and correlation coefficient $\left(R^{2}\right)$ values for different metal ions biosorption onto raw (RB) and Fenton modified biosorbent (FMDBH) are shown in Table 2. Langmuir $Q_{\max }$ values as obtained were $27.86,50.66,32.14$, and $40.43 \mathrm{mg} \mathrm{g}^{-1}$ for $\mathrm{RB}$ and $106.23,109.32,108.56$, and $110.78 \mathrm{mg} \mathrm{g}^{-1}$ for FMDBH for $\mathrm{Cu}^{2+}, \mathrm{Zn}^{2+}, \mathrm{Pb}^{2+}$, and $\mathrm{Cd}^{2+}$, respectively. This clearly shows that the Fenton modification of the biomass significantly enhanced the biosorption capacity.Freundlich model is expressed by the equation

$Q_{\mathrm{e}}=K_{\mathrm{f}} \times C_{\mathrm{e}}^{1 / n}$

where $K_{\mathrm{f}}\left(\mathrm{mg} \mathrm{g}^{-1}\right)$ is the Freundlich constant or biosorption capacity and $n$ denotes the biosorption intensity. In order to fit the experimental data, the linearized Freundlich expression was utilized, which is described by the equation given as follows: $\ln Q_{\mathrm{e}}=\ln K_{\mathrm{f}}+\frac{1}{n} \ln C_{\mathrm{e}}$

Freundlich isotherm constants and correlation coefficients $\left(R^{2}\right)$ values are given in Table 2. The value of $K_{\mathrm{f}}$ increased after the Fenton modification process, which shows that modification process enhances the biosorption capacity. The percentage increase in the biosorption capacity after modification process follows the sequence: $\mathrm{Cu}^{2+}>\mathrm{Pb}^{2+}>\mathrm{Cd}^{2+}>\mathrm{Zn}^{2+}$. The elevated affinity of the modified biomass for metal ions was also imitated by $1 /$ $n$ values. The value of $1 / n<1$ shows the favorable biosorption. Both the isotherm models fit the experimental data reasonably well, but after comparing $R^{2}$ values, it can be observed that the Freundlich isotherm model fits the experimental data better than the Langmuir model.

\section{Multi-component system}

For multi-metal system studies, RB and FMDBH were suspended separately in $50 \mathrm{ml}$ of multi-metal solution containing $10.0 \mathrm{mg} \mathrm{L}^{-1}$ of each metal ion $\left(\mathrm{Cu}^{2+}, \mathrm{Zn}^{2+}\right.$, $\mathrm{Pb}^{2+}$, and $\left.\mathrm{Cd}^{2+}\right)$ at $\mathrm{pH}$ 5. The results are shown in Fig. 5. The biosorption capacities of both RB and FMDBH for multi-metal solution were relatively lower in comparison with the single-metal solution. This may be due to differences in ionic charge, radii, and electrode potential of different metals which affects the overall multi-metal ions biosorption (Saygideger et al. 2005). Further, the biosorption capacity of FMDBH for multi-metal solution was better than the RB, suggesting the increase in biosorption capacity after Fenton modification process.

\section{Biosorption kinetic studies}

In the present research study, two different biosorption kinetic models, viz, pseudo-first-order and pseudo-secondorder models, were employed to the experimentally obtained biosorption data. The biosorption kinetic studies were performed separately for RB and FMDBH. The 
Fig. 5 Effect of single- and multi-metal ions on biosorption capacities of FMDBH and raw biomass

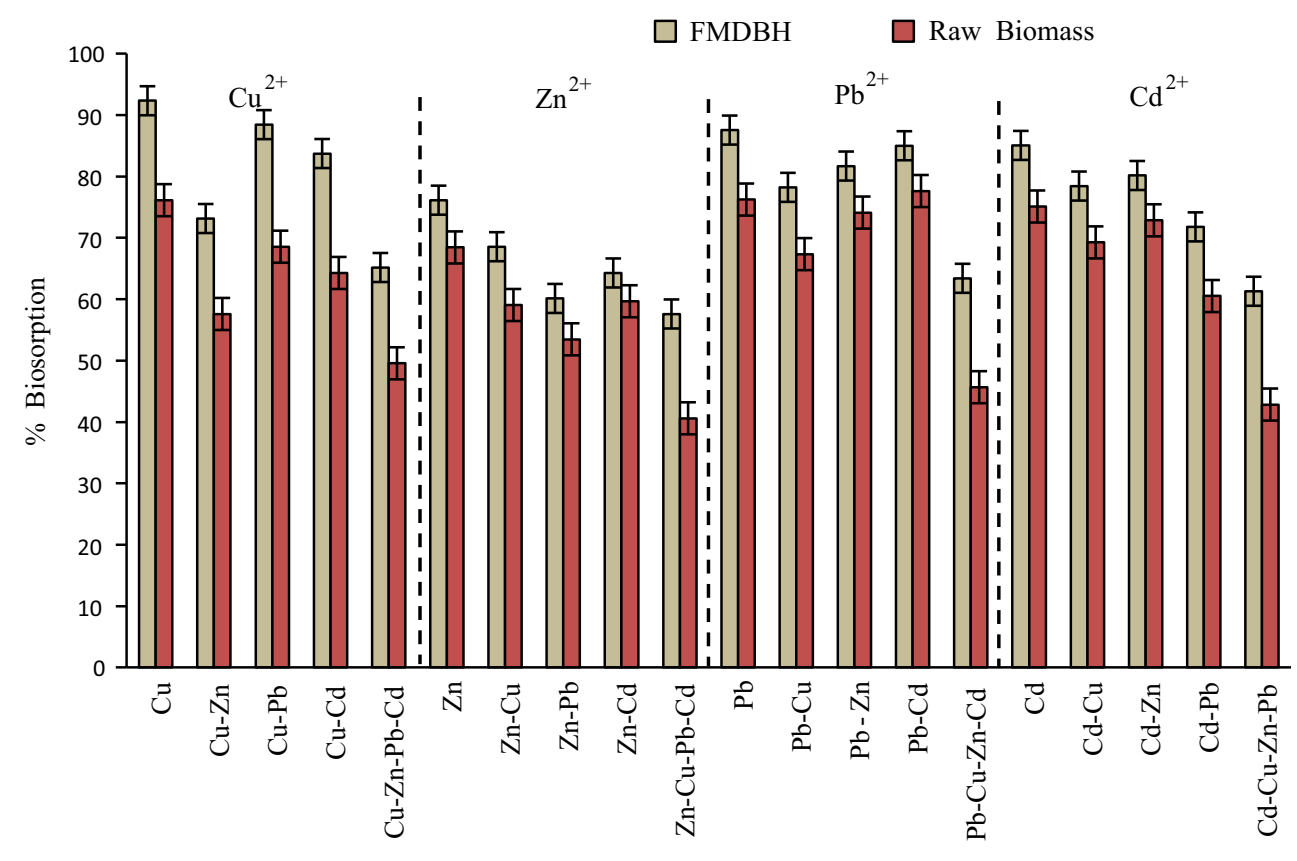

pseudo-first-order (Lagergren 1898) rate equation which is expressed as follows:

$\log \left(Q_{\mathrm{e}}-Q_{\mathrm{t}}\right)=\log Q_{\mathrm{e}}-\frac{k_{1} t}{2.303}$

was used to fit the experimental data, where $Q_{\mathrm{e}}\left(\mathrm{mg} \mathrm{g}^{-1}\right)$ and $Q_{\mathrm{t}}\left(\mathrm{mg} \mathrm{g}^{-1}\right)$ are the amount of metal ions biosorbed at equilibrium and at time $t$, respectively. $k_{1}\left(\mathrm{~min}^{-1}\right)$ is the biosorption rate constant. The values of $k_{1}$ and $Q_{e}$ (cal.) can be obtained from the slope and intercept of the plot between $\log \left(Q_{\mathrm{e}}-Q_{\mathrm{t}}\right)$ and $\mathrm{t}$. The biosorption rate constant $\left(k_{1}\right)$ and their corresponding correlation coefficient $\left(R^{2}\right)$ values is given in the Table 3 . As it can be observed from the Table 3, the calculated values of $Q_{\mathbf{e}}$ (cal.) obtained from the intercept of plot greatly differ from the experimental values of $Q_{\mathrm{e}}$. Moreover, the $R^{2}$ values were relatively low for all the studied metal ions. Hence, it can be concluded that the pseudo-first-order model cannot be appropriate to predict the biosorption reaction kinetics in this case. As a consequence of the non-suitability of pseudo-first-order rate equation, the experimental data were further analyzed using pseudo-second-order model. The linear form of the pseudo-second-order model is expressed as (Ho and McKay 1999):

$\frac{t}{Q_{t}}=\frac{t}{Q_{\mathrm{e}}}+\frac{1}{k_{2} Q_{\mathrm{e}}^{2}}$

where $Q_{\mathrm{e}}\left(\mathrm{mg} \mathrm{g}^{-1}\right)$ and $Q_{\mathrm{t}}\left(\mathrm{mg} \mathrm{g}^{-1}\right)$ are the amount of metal ions biosorbed at equilibrium and at time $t$, respectively. $k_{2}\left(\mathrm{~g} \mathrm{mg}^{-1} \mathrm{~min}^{-1}\right)$ is the biosorption rate constant and $t$ is the contact time (min). The values of $k_{2}$ and $Q_{\mathrm{e}}$ (cal.) can be obtained from the slope and intercept of the plot between $t / Q_{t}$ and $t$. The rate constant $k_{2}$, the calculated values of $Q_{\mathrm{e}}$ (cal.), and their corresponding correlation coefficient $\left(R^{2}\right)$ values are shown in the Table 3 . The calculated values of $Q_{\mathrm{e}}$ (cal.) determined from the intercept of plot matches with the experimental values of $Q_{\mathrm{e}}$. Furthermore, the correlation coefficient $\left(R^{2}\right)$ values were higher for all the metal ions studied. Thus, it can be concluded that the pseudo-second-order rate equation fits the experimental data relatively better than the pseudo-first-order rate equation, supporting the postulation that the chemisorption may be the rate-limiting step in this case.

\section{Comparative studies}

Comparison of raw and Fenton modified $H$. verticillata dried biomass with other adsorbents or biosorbents for $\mathrm{Cu}^{2+}, \mathrm{Zn}^{2+}, \mathrm{Pb}^{2+}$, and $\mathrm{Cd}^{2+}$ ions removal was presented in Table 4. From the table, it can be concluded that the FMDBH is much more efficient in removing $\mathrm{Cu}^{2+}, \mathrm{Zn}^{2+}$, $\mathrm{Pb}^{2+}$, and $\mathrm{Cd}^{2+}$ ions from wastewater compared to other adsorbents or biosorbents reported earlier. Although many bacterial biosorbents have shown their potential (Table 4) for metal removal from wastewater, they present some disadvantages such as requirement of centrifugation for biomass concentration stage and chemical agents for immobilization process for the production of granulated or agglomerated products. Both are very expensive processes that demand a high energetic cost and utilize toxic chemical products or environmental contaminants. Moreover, the other difficulties are production and transportation of 
Table 3 Fitting parameters for pseudo-first-order and pseudo-second-order along with their correlation coefficients $\left(R^{2}\right)$ values

\begin{tabular}{|c|c|c|c|c|c|c|c|c|c|}
\hline \multirow{2}{*}{$\begin{array}{l}\text { Metal } \\
\text { ions }\end{array}$} & \multirow[t]{2}{*}{ Treatment } & \multirow{2}{*}{$\begin{array}{l}\text { Temperature } \\
(\mathrm{K})\end{array}$} & \multirow{2}{*}{$\begin{array}{l}\mathrm{Q}_{\mathrm{e}}\left(\mathrm{mg} \mathrm{g}^{-1}\right) \\
\text { experimental }\end{array}$} & \multicolumn{3}{|c|}{ Pseudo-first-order model } & \multicolumn{3}{|c|}{ Pseudo-second-order model } \\
\hline & & & & $\begin{array}{l}K_{1} \\
\left(\min ^{-1}\right)\end{array}$ & $\begin{array}{l}\mathrm{Q}_{\mathrm{e}} \\
\left(\mathrm{mg} \mathrm{g}^{-1}\right)\end{array}$ & $\mathrm{R}^{2}$ & $\begin{array}{l}K_{2}\left(\mathrm{~g} \mathrm{mg}^{-1}\right. \\
\left.\mathrm{min}^{-1}\right)\end{array}$ & $\begin{array}{l}\mathrm{Q}_{\mathrm{e}} \\
\left(\mathrm{mg} \mathrm{g}^{-1}\right)\end{array}$ & $\mathrm{R}^{2}$ \\
\hline \multirow[t]{6}{*}{$\mathrm{Cu}^{2+}$} & \multirow[t]{3}{*}{ Raw biomass } & 293 & 45 & 0.1267 & 29 & 0.745 & 0.0728 & 46 & 0.932 \\
\hline & & 303 & 42 & 0.0745 & 26 & 0.667 & 0.0956 & 42 & 0.999 \\
\hline & & 313 & 41 & 0.0785 & 24 & 0.632 & 0.0945 & 40 & 0.969 \\
\hline & \multirow{3}{*}{$\begin{array}{l}\text { Fenton modified } \\
\text { biomass }\end{array}$} & 293 & 78 & 0.0582 & 58 & 0.768 & 0.0778 & 78 & 0.995 \\
\hline & & 303 & 75 & 0.0680 & 61 & 0.792 & 0.0834 & 72 & 0.992 \\
\hline & & 313 & 71 & 0.0459 & 55 & 0.831 & 0.0952 & 73 & 0.984 \\
\hline \multirow[t]{6}{*}{$\mathrm{Zn}^{2+}$} & \multirow[t]{3}{*}{ Raw biomass } & 293 & 37 & 0.0521 & 30 & 0.714 & 0.0743 & 39 & 0.976 \\
\hline & & 303 & 32 & 0.0478 & 26 & 0.798 & 0.0690 & 32 & 0.988 \\
\hline & & 313 & 31 & 0.0715 & 24 & 0.663 & 0.0561 & 30 & 0.969 \\
\hline & \multirow{3}{*}{$\begin{array}{l}\text { Fenton modified } \\
\text { biomass }\end{array}$} & 293 & 59 & 0.0638 & 47 & 0.827 & 0.0814 & 59 & 0.997 \\
\hline & & 303 & 57 & 0.0587 & 44 & 0.705 & 0.0674 & 57 & 0.994 \\
\hline & & 313 & 55 & 0.0668 & 39 & 0.749 & 0.0755 & 53 & 0.932 \\
\hline \multirow[t]{6}{*}{$\mathrm{Pb}^{2+}$} & \multirow[t]{3}{*}{ Raw biomass } & 293 & 43 & 0.1024 & 31 & 0.803 & 0.0429 & 46 & 0.999 \\
\hline & & 303 & 40 & 0.1035 & 30 & 0.796 & 0.0530 & 41 & 0.969 \\
\hline & & 313 & 38 & 0.0953 & 26 & 0.751 & 0.0468 & 37 & 0.978 \\
\hline & \multirow{3}{*}{$\begin{array}{l}\text { Fenton modified } \\
\text { biomass }\end{array}$} & 293 & 69 & 0.0732 & 49 & 0.711 & 0.0542 & 68 & 0.991 \\
\hline & & 303 & 68 & 0.0581 & 45 & 0.725 & 0.0567 & 68 & 0.999 \\
\hline & & 313 & 68 & 0.0554 & 48 & 0.818 & 0.0535 & 66 & 0.987 \\
\hline \multirow[t]{6}{*}{$\mathrm{Cd}^{2+}$} & \multirow[t]{3}{*}{ Raw biomass } & 293 & 41 & 0.0916 & 25 & 0.682 & 0.0764 & 41 & 0.983 \\
\hline & & 303 & 40 & 0.0632 & 29 & 0.667 & 0.0854 & 42 & 0.977 \\
\hline & & 313 & 35 & 0.0805 & 27 & 0.694 & 0.0837 & 34 & 0.982 \\
\hline & \multirow{3}{*}{$\begin{array}{l}\text { Fenton modified } \\
\text { biomass }\end{array}$} & 293 & 68 & 0.0457 & 46 & 0.708 & 0.0698 & 68 & 0.993 \\
\hline & & 303 & 64 & 0.0428 & 41 & 0.738 & 0.0871 & 63 & 0.995 \\
\hline & & 313 & 61 & 0.0586 & 39 & 0.712 & 0.0982 & 60 & 0.992 \\
\hline
\end{tabular}

inoculants to the decontamination site as this is restricted by the low stability of the inoculant culture and their requirement in huge volume (Cotoras and Viedma 2011). Since these kinds of disadvantages are not associated with current method suggested for the removal of metal ions form wastewater, it can be concluded that the current method is better, economically cheaper, and environmentfriendly than the aforesaid biosorbent as this has already been discussed previously in the introduction section.

Thermodynamic studies

Experiments were carried out at 293,303 , and $313 \mathrm{~K}$ to examine the thermodynamic characteristics of metal ions biosorption process using only FMDBH. To assess the feasibility of the process, different thermodynamic parameters were estimated using the equation given as follows:

$\Delta G^{\mathrm{o}}=-R T \ln K_{\mathrm{o}}$

where $\Delta G^{\mathrm{O}}$ is standard free energy change, $R$ is the universal gas constant $(8.314 \mathrm{~J} / \mathrm{mol} / \mathrm{K}), T$ is the absolute temperature, and $K_{\mathrm{o}}$ is the thermodynamic constant. $K_{\mathrm{o}}$ values can be determined by plotting a graph between $\ln$ $\mathrm{Q}_{\mathrm{e}} / \mathrm{C}_{\mathrm{e}}$ versus $\mathrm{Q}_{\mathrm{e}}$ at different temperatures, where $\mathrm{Q}_{\mathrm{e}}$ is the amount of metal ions biosorbed by FMDBH and $C_{e}$ is the metal ions concentration in the solution at equilibrium. The change in enthalpy $\left(\triangle H^{\mathrm{O}}\right)$ and entropy $\left(\triangle S^{\mathrm{O}}\right)$ was determined by the following equation:

$\ln K_{\mathrm{o}}=\frac{\Delta S^{\mathrm{o}}}{R}-\frac{\Delta H^{\mathrm{o}}}{R T}$

The change in enthalpy $\left(\triangle H^{\mathrm{O}}\right)$ and entropy $\left(\triangle S^{\mathrm{O}}\right)$ was estimated from the slope and intercept of the plot between $\ln K_{\mathrm{o}}$ versus $1 / \mathrm{T}$. With increase in temperature from 293 to $313 \mathrm{~K}$, the value of Gibbs free energy decreases from 3.63 to $-7.45,-1.56$ to $-6.21,-3.92$ to -5.66 , and -2.58 to -4.96 for $\mathrm{Cu}^{2+}, \mathrm{Zn}^{2+}, \mathrm{Pb}^{2+}$, and $\mathrm{Cd}^{2+}$ ions, respectively (Table 5). This might be due to increase in the degree of protonation of carboxylic and amine groups on the surface of FMDBH with rise in temperature (Biesuz et al. 1997; Donais et al. 1999). The change in enthalpy $\left(\triangle H^{\mathrm{O}}\right)$ and entropy $\left(\triangle S^{\mathrm{O}}\right)$ was found to be -68.46 , $59.42,-65.18$, and -61.83 ; and $-0.344,-0.198,-0.384$, 
Table 4 Comparison of raw biomass (RB) and Fenton modified $H$. verticillata dried biomass (FMDBH) with other adsorbent or biosorbent

\begin{tabular}{|c|c|c|c|c|c|}
\hline \multirow[t]{2}{*}{ Biosorbent } & \multicolumn{4}{|c|}{ Biosorption capacity $\left(\mathrm{mg} \mathrm{g}^{-1}\right)$} & \multirow[t]{2}{*}{ References } \\
\hline & $\mathrm{Cu}^{2+}$ & $\mathrm{Zn}^{2+}$ & $\mathrm{Pb}^{2+}$ & $\mathrm{Cd}^{2+}$ & \\
\hline $\begin{array}{l}\text { Dairy manure } \\
\text { compost }\end{array}$ & - & - & 95.31 & - & $\begin{array}{l}\text { Zhang } \\
\text { (2011) }\end{array}$ \\
\hline $\begin{array}{c}\text { Pseudomonas } \\
\text { putida } \mathrm{CZ1}\end{array}$ & 15.8 & 17.7 & & & $\begin{array}{l}\text { Chen et al. } \\
\text { (2005) }\end{array}$ \\
\hline $\begin{array}{l}\text { Pseudomonas } \\
\text { putida }\end{array}$ & & 6.9 & 56.2 & & $\begin{array}{l}\text { Pardo et al. } \\
\text { (2003) }\end{array}$ \\
\hline $\begin{array}{l}\text { Bacillus } \\
\text { circulans }\end{array}$ & & & & 26.5 & $\begin{array}{l}\text { Yilmaz and } \\
\text { Ensari } \\
(2005)\end{array}$ \\
\hline $\begin{array}{l}\text { Thiobacillus } \\
\text { ferrooxidans }\end{array}$ & & 82.6 & & & $\begin{array}{l}\text { Celaya et al. } \\
(2000)\end{array}$ \\
\hline $\begin{array}{l}\text { Marine green } \\
\text { algae (Ulva } \\
\text { fasciata } \text { sp.) }\end{array}$ & - & 13.5 & - & - & $\begin{array}{l}\text { Kumar et al. } \\
\text { (2007) }\end{array}$ \\
\hline $\begin{array}{l}\text { Sulfured orange } \\
\text { peel }\end{array}$ & & 80 & 164 & - & $\begin{array}{l}\text { Liang et al. } \\
\text { (2011) }\end{array}$ \\
\hline Saw dust & 6.58 & - & 21.05 & - & $\begin{array}{l}\text { Li et al. } \\
\text { (2007) }\end{array}$ \\
\hline $\begin{array}{l}\text { Activated } \\
\text { carbon from } \\
\text { sea-buckthorn } \\
\text { stones }\end{array}$ & - & - & 25.91 & - & $\begin{array}{l}\text { Mohammadi } \\
\text { et al. } \\
\text { (2010) }\end{array}$ \\
\hline $\begin{array}{r}\text { Spirogyra } \\
\text { neglecta }\end{array}$ & 40.83 & 31.51 & 90.19 & 27.95 & $\begin{array}{l}\text { Singh et al. } \\
\text { (2007) }\end{array}$ \\
\hline Peanut shell & - & - & 38.91 & - & $\begin{array}{l}\text { Tasar et al. } \\
\text { (2014) }\end{array}$ \\
\hline Carrot residue & - & 29.61 & - & - & $\begin{array}{l}\text { Nasernejad } \\
\text { et al. } \\
(2005)\end{array}$ \\
\hline $\begin{array}{l}\text { Pine cone } \\
\text { activated } \\
\text { carbon }\end{array}$ & - & - & 27.53 & - & $\begin{array}{l}\text { Momcilovic } \\
\text { et al. } \\
\text { (2011) }\end{array}$ \\
\hline $\begin{array}{l}\text { Azadirachta } \\
\text { indica } \text { bark }\end{array}$ & - & 33.49 & - & - & $\begin{array}{l}\text { King et al. } \\
(2008)\end{array}$ \\
\hline $\begin{array}{l}\text { Penicillium } \\
\text { citrinum } \\
\text { (immobilized } \\
\text { biomass) }\end{array}$ & 25 & - & - & - & $\begin{array}{l}\text { Verma et al. } \\
\text { (2013) }\end{array}$ \\
\hline $\begin{array}{l}\text { Jute fibers } \\
\text { treated with } \\
\mathrm{H}_{2} \mathrm{O}_{2}\end{array}$ & - & 8.02 & - & - & $\begin{array}{l}\text { Shukla and } \\
\text { Pai (2005) }\end{array}$ \\
\hline $\begin{array}{l}\text { Lemna minor L. } \\
\text { (Alkali- } \\
\text { treated) }\end{array}$ & 69 & - & - & 83 & $\begin{array}{l}\text { Saygideger } \\
\text { et al. } \\
\text { (2005) }\end{array}$ \\
\hline $\begin{array}{l}\text { Pithophora } \\
\text { odeogonia }\end{array}$ & 23.08 & 8.98 & 71.13 & 13.07 & $\begin{array}{l}\text { Singh et al. } \\
(2007)\end{array}$ \\
\hline $\begin{array}{l}\text { Cashew nut } \\
\text { shell }\end{array}$ & - & - & 17.82 & - & $\begin{array}{l}\text { Kumar } \\
\text { (2014) }\end{array}$ \\
\hline $\begin{array}{l}\text { Pleurotus } \\
\text { ostreatus }\end{array}$ & - & - & - & 4.05 & $\begin{array}{l}\text { Tay et al. } \\
\text { (2011) }\end{array}$ \\
\hline $\mathrm{RB}$ & 27.86 & 50.66 & 32.14 & 40.43 & Present study \\
\hline FMDBH & 106.23 & 109.32 & 108.56 & 110.78 & Present study \\
\hline
\end{tabular}

Table 5 Thermodynamic parameter for biosorption of $\mathrm{Cu}^{2+}, \mathrm{Zn}^{2+}$, $\mathrm{Pb}^{2+}$, and $\mathrm{Cd}^{2+}$

\begin{tabular}{llll}
\hline Metal ions & Temperature $(\mathrm{K})$ & $\ln \boldsymbol{K}_{o}$ & $\Delta \boldsymbol{G}^{\mathrm{O}}\left(\mathrm{KJ} \mathrm{mol}^{-1}\right)$ \\
\hline $\mathrm{Cu}^{2+}$ & 293 & 45 & -3.63 \\
& 303 & 42 & -5.84 \\
& 313 & 41 & -7.45 \\
$\mathrm{Zn}^{2+}$ & 293 & 37 & -1.56 \\
& 303 & 32 & -4.34 \\
& 313 & 31 & -6.21 \\
$\mathrm{~Pb}^{2+}$ & 293 & 43 & -3.92 \\
& 303 & 40 & -4.27 \\
& 313 & 38 & -5.66 \\
$\mathrm{Cd}^{2+}$ & 293 & 41 & -2.58 \\
& 303 & 40 & -3.63 \\
& 313 & 35 & -4.96 \\
\hline
\end{tabular}

Table 6 Percentage removals of metal ions from wastewater using $\mathrm{RB}$ and FMDBH

\begin{tabular}{llll}
\hline $\begin{array}{l}\text { Metal } \\
\text { ions }\end{array}$ & $\begin{array}{l}\text { Concentration (mg } \\
\mathrm{L}^{-1} \text { ) before } \\
\text { biosorption }\end{array}$ & $\begin{array}{l}\text { \% Removal after } \\
\text { raw biomass } \\
\text { biosorption }\end{array}$ & $\begin{array}{l}\text { \% Removal after } \\
\text { FMDBH } \\
\text { biosorption }\end{array}$ \\
\hline $\mathrm{Cu}^{2+}$ & 4.64 & $74 \%$ & $96 \%$ \\
$\mathrm{Zn}^{2+}$ & 3.75 & $67 \%$ & $84 \%$ \\
$\mathrm{~Pb}^{2+}$ & 1.34 & $71 \%$ & $92 \%$ \\
$\mathrm{Cd}^{2+}$ & 3.28 & $71 \%$ & $89 \%$ \\
\hline
\end{tabular}

and -0.275 for $\mathrm{Cu}^{2+}, \mathrm{Zn}^{2+}, \mathrm{Pb}^{2+}$, and $\mathrm{Cd}^{2+}$ ions, respectively. Thus, it can be concluded that the biosorption process using FMDBH was spontaneous, chemically governed and exothermic in nature. Similar results were also reported by the other researchers (Huang et al. 2010).

Performance of batch reactor in treating wastewater

Since the main aim of the biosorption technology was to treat the wastewater laden with several metal ions, the batch experiments were also carried out by utilizing wastewater samples instead of metal solutions under same experimental conditions. Significant increase in removal efficiency of $\mathrm{Cu}^{2+}$ (from 74 to $96 \%$ ), $\mathrm{Zn}^{2+}$ (from 67 to $84 \%), \mathrm{Pb}^{2+}(71-92 \%)$, and $\mathrm{Cd}^{2+}(71-89 \%)$ ions were observed after the modification of biosorbent as compared to RB (Table 6).

\section{Conclusion}

In order to enhance the biosorption capacity of $H$. verticillata dried biomass, Fenton reagent was used. For Fenton 
modification process, the optimum values of $\mathrm{pH}$, biosorbent dose, contact time, and $\mathrm{Fe}^{2+} / \mathrm{H}_{2} \mathrm{O}_{2}$ ratio were 3.5, $80 \mathrm{~g} \mathrm{~L}^{-1}, 60 \mathrm{~min}$, and $0.01 \mathrm{w} / \mathrm{w}$, respectively. EDX analysis revealed the enhancement in the weight percent of $\mathrm{Cu}^{2+}(47.53 \%), \mathrm{Zn}^{2+}(41.82 \%), \mathrm{Pb}^{2+}(43.76 \%)$, and $\mathrm{Cd}^{2+}(43.15 \%)$ ions on the surface of FMDBH after the biosorption. Results revealed that the Freundlich isotherm model fits the data better than the Langmuir isotherm model. The biosorption process followed the pseudo-second-order kinetics, suggesting that the chemisorption may be the rate-limiting step in this study. Thermodynamic study showed that the biosorption process was spontaneous and exothermic in nature. In case of multi-metal solution, the biosorption capacity was found to be relatively lower than the single-metal solution. Performance of batch reactor in treating secondary effluent using FMDBH showed significant reduction in the concentration of $\mathrm{Cu}^{2+}$, $\mathrm{Zn}^{2+}, \mathrm{Pb}^{2+}$, and $\mathrm{Cd}^{2+}$ ions after the biosorption process. Thus, it can be concluded that the FMDBH could be efficiently used to remove metal ions from wastewater.

Acknowledgments Authors are thankful to the University Grants Commission (UGC) (Ref. No.: R-Dev-S. UGC-Research Fellow/ 2012-13/6417/01-06-2012), India, for providing financial support. Institute of Environment and Sustainable Development and Centre of Advanced Study in Botany, Banaras Hindu University (BHU), Varanasi, India, for providing necessary infrastructure. Authors are also thankful to the staff of Department of Chemistry, BHU and National Electron Microscope Facility, Department of Metallurgy, Indian Institute of Technology, Banaras Hindu University, Varanasi, India, for FT-IR and SEM-EDX characterization.

\section{References}

Aldor I, Fourest E, Volesky B (1995) Desorption of cadmium from algal biosorbent. Can J Chem Eng 73:516-522

APHA (2012) Standard methods for the examination of water and wastewater, 22nd edition American Public Health Association, American Water Works Association, and Water Environment Federation: Washington

Argun ME, Dursun S (2008) A new approach to modification of natural adsorbent for heavy metal adsorption. Bioresour Technol 99:2516-2527

Baral SS, Das N, Chaudhury GR, Das SN (2009) A preliminary study on the adsorptive removal of $\mathrm{Cr}(\mathrm{VI})$ using seaweed, Hydrilla verticillata. J Hazard Mater 171:358-369

Barka N, Ouzaouit K, Abdennouri M, Makhfouk ME (2013) Dried prickly pear cactus (Opuntia ficus indica) cladodes as a low-cost and eco-friendly biosorbent for dyes removal from aqueous solutions. J Taiwan Inst Chem Eng 44:52-60

Bhatti HN, Hamid S (2014) Removal of uranium (VI) from aqueous solutions using Eucalyptus citriodora distilliation sludge. Int J Environ Sci Technol 11:813-822

Biesuz R, Pesavento M, Gonzalo A, Valiente M (1997) Sorption of proton and heavy metal ions on a macroporous chelating resin with an iminodiacetate active group as a function of temperature. Talanta 47:127-136
BIS (Bureau of Indian Standard Specification) (1993) IS 10500, India

Blazquez G, Martin-Lara MA, Dionisio-Ruiz E, Tenorio G, Calero M (2012) Copper biosorption by pine cone shell and thermal decomposition study of the exhausted biosorbent. J Ind Eng Chem 18:1741-1750

Cardoso VA, de Souza AG, Sartoratto PPC, Nunes LM (2004) The ionic exchange process of cobalt, nickel and copper (II) in alkaline and acid-layered titanates. Colloid Surface A 248:145-149

Celaya RJ, Noriega JA, Yeomans JH, Ortega LJ, Ruiz-Manriquez A (2000) Biosorption of $\mathrm{Zn}$ by Thiobacillus ferrooxidans. Bioprocess Eng 22:539-542

Chen XC, Wang YP, Lin Q, Shi JY, Wu WX, Chen YX (2005) Biosorption of copper(II) and zinc(II) from aqueous solution by Pseudomonas putida CZ1. Colloids Surf B Biointerfaces 46:101-107

Cotoras D, Viedma P (2011) Bacterial strain for a metal biosorption process. US Patent No. 7951578B2

Davis TA, Volesky B, Vieira RHSF (2000) Sargassum seaweed as biosorbent for heavy metals. Water Res 34:4270-4278

Dekhil AB, Hannachi Y, Ghorbel A, Boubaker T (2011) Removal of lead and cadmium ions from aqueous solutions using dried marine green macroalga (Caulerpa racemosa). Int J Environ Res 5(3):725-732

Deng PY, Liu W, Zeng BQ, Qiu YK, Li LS (2013) Sorption of heavy metals from aqueous solution by dehydrated powders of aquatic plants. Int J Environ Sci Technol 10:559-566

Donais MK, Henry R, Rettberg T (1999) Chromium speciation using an automated liquid handling system with inductively coupled plasma-mass spectrometric detection. Talanta 49:1045-1050

Ekmekyapar F, Aslan A, Bayhan YK, Cakici A (2012) Biosorption of $\mathrm{Pb}(\mathrm{II})$ by nonliving lichen biomass of Cladonia rangiformis Hoffm. Int J Environ Res 6(2):417-424

EPA (Environmental Protection Agency) (2004) USA, National pollutant discharge elimination system (NPDES) [http://www. cfpub.epa.gov/npdes/home.cfm?program_id=3]

Fatima T, Nadeem R, Masood A, Saeed R, Asraf M (2013) Sorption of lead by chemically modified rice bran. Int $\mathrm{J}$ Environ Sci Technol 10:1255-1264

Freundlich HMF (1906) Over the adsorption in solution. J Phys Chem US 57:385-470

Gilbert UA, Emmanuel IU, Adebanjo AA, Olalere GA (2011) Biosorptive removal of $\mathrm{Pb}^{2+}$ and $\mathrm{Cd}^{2+}$ onto novel biosorbent: defatted Carica papaya seeds. Biomass Bioenergy 35:2517-2525

Gupta R, Ahuja P, Khan S, Saxena RK, Mohapatra H (2000) Microbial biosorbents: meeting challenges of heavy metal pollution in aqueous solutions. Current Sci 78:967-973

Gupta N, Amritphale SS, Chandra N (2010) Removal of Zn (II) from aqueous solution by using hybrid precursor of silicon and carbon. Bioresour Technol 101:3355-3362

Hawari AH, Mulligan CN (2006) Biosorption of lead (II), cadmium (II), copper (II) and nickel (II) by anaerobic granular biomass. Bioresour Technol 97:692-700

Ho Y, McKay G (1999) Pseudo-second order model for sorption process. Process Biochem 34:451-465

Huang L, Zeng G, Huang D, Li L, Du C, Zhang L (2010) Biosorption of cadmium(II) from aqueous solution onto Hydrilla verticillata. Environ Earth Sci 60:1683-1691

Janson CE, Kenson RE, Tucker LH (1982) Treatment of heavy metals in wastewaters. Environ Prog 1:212-216

Kakarla PK, Andrews T, Greenberg RS, Zervas D (2002) ModifiedFenton's processes for effective in situ chemical oxidationlaboratory and field evaluation. Remediat J 12:23-36 
King P, Anuradha K, Lahari SB, Kumar YP, Prasad VSRK (2008) Biosorption of zinc from aqueous solution using Azadirachta indica bark: equilibrium and kinetic studies. J Hazard Mater 152:324-329

$\mathrm{Ku}$ Y, Jung IL (2001) Photocatalytic reduction of $\mathrm{Cr}$ (VI) in aqueous solutions by UV irradiation with the presence of titanium dioxide. Water Res 35:135-142

Kumar PS (2014) Adsorption of lead (II) ions from simulated wastewater using natural waste: a kinetic, thermodynamic and equilibrium study. Environ Prog Sustain Energ 33(1):55-64

Kumar YP, King P, Prasad VSRK (2006) Zinc biosorption on Tectona grandis L.f. leaves biomass: equilibrium and kinetic studies. Chem Eng J 124:63-70

Kumar YP, Ring P, Prasad VSRK (2007) Adsorption of zinc from aqueous solution using marine green algae-Ulva fasciata sp. Chem Eng J 129:161-166

Lagergren S (1898) About the theory of so called adsorption of solute substances. Kungliga Svenska, Vetenskapsakad. Handemiens. Handlingar. Band 24 (4):1-39

Lai CL, Lin SH (2003) Electrocoagulation of chemical mechanical polishing (CMP) wastewater from semiconductor fabrication. Chem Eng J 95:205-211

Langmuir I (1916) The adsorption gasses on plane surface of glass, mica and platinum. J Am Chem Soc 40:1361-1368

Li Q, Zhai J, Zhang W, Wang M, Zhou J (2007) Kinetic studies of adsorption of $\mathrm{Pb}(\mathrm{II}), \mathrm{Cr}$ (III) and $\mathrm{Cu}$ (II) from aqueous solution by sawdust and modified peanut husk. J Hazard Mater 141:163-167

Li CW, Chen YM, Hsiao ST (2008) Compressed air-assisted solvent extraction (CASX) for metal removal. Chemosphere 71:51-58

Li GZ, Yan CZ, Zhang DD, Zhao C, Chen GY (2013) Cadmium (II) biosorption from aqueous solutions using Hydrilla verticillata. Can J Chem Eng 91:1022-1030

Liang S, Guo X, Tian Q (2011) Adsorption of $\mathrm{Pb}^{2+}$ and $\mathrm{Zn}^{2+}$ from aqueous solutions by sulfured orange peel. Desalination 275:212-216

Lundh M, Jönsson L, Dahlquist J (2000) Experimental studies of the fluid dynamics in the separation zone in dissolved air flotation. Water Res 34:21-30

Mane PC, Bhosle AB (2012) Bioremoval of some metals by living algae Spirogyra sp. and Spirullina sp. from aqueous solution. Int. J Environ Res 6(2):571-576

Medina BY, Torem ML, de Mesquita LMS (2005) On the kinetics of precipitate flotation of Cr III using sodium dodecylsulfate and ethanol. Miner Eng 18:225-231

Miretzky P, Munoz C (2011) Enhanced metal removal from aqueous solution by Fenton activated macrophyte biomass. Desalination 271:20-28

Mohammadi SZ, Karimi MA, Afzali D, Mansouri F (2010) Removal of $\mathrm{Pb}$ (II) from aqueous solutions using activated carbon from sea-buckthorn stones by chemical activation. Desalination 262:86-93

Mohsen-Nia M, Montazeri P, Modarress H (2007) Removal of $\mathrm{Cu}^{2+}$ and $\mathrm{Ni}^{2+}$ from wastewater with a chelating agent and reverse osmosis processes. Desalination 217:276-281

Momcilovic M, Purenovic M, Bojic A, Zarubica A, Randelovic M (2011) Removal of lead (II) ions from aqueous solutions by adsorption onto pine cone activated carbon. Desalination 276:53-59

Munter R (2001) Advanced oxidation processes-current status and prospects. Proc Estonian Acad Sci Chem 59-65

Nasernejad B, Zadeh TE, Pour BB, Bygi ME, Zamani A (2005) Comparison for biosorption modeling of heavy metals ( $\mathrm{Cr}(\mathrm{III})$, $\mathrm{Cu}$ (II), Zn (II)) adsorption from wastewater by carrot residues. J Process Biochem 40:1319-1322
Naveen N, Saravanan P, Baskar G, Renganathan S (2011) Equilibrium and kinetic modeling on the removal of Reactive Red 120 using positively charged Hydrilla verticillata. J Taiwan Inst Chem Eng 42:463-469

Nidheesh PV, Gandhimati R, Ramesh ST (2013) Degradation of dyes from aqueous solution by Fenton processes: a review. Environ Sci Pollut Res 20:2099-2132

Nigam S, Gopal K, Vankar PS (2013) Biosorption of arsenic in drinking water by submerged plant: hydrilla verticilata. Environ Sci Pollut Res 20:4000-4008

Pardo R, Herguedas M, Barrado E, Vega M (2003) Biosorption of cadmium, copper, lead and zinc by inactive biomass of Pseudomonas putida. Anal Bioanal Chem 376:26-32

Pignatello JJ, Oliveros E, MacKay A (2006) Advanced oxidation processes for organic contaminant destruction based on the Fenton reaction and related chemistry. Crit Rev Environ Sci Technol 36:1-84

Pouran SR, Raman AAA, Daud WMAW (2013) Review on the application of modified iron oxides as heterogeneous catalysts in Fenton reactions. J Clean Prod 64:24-35

Puranik PR, Paknikar KM (1999) Biosorption of Lead, Cadmium, and Zinc by Citrobacter Strain MCM B-181: characterization studies. Biotechnol Progr 15:228-237

San Sebastian N, Fernandez JF, Segura XF, Ferrer AS (2003) Preoxidation of an extremely polluted industrial wastewater by the Fenton's reagent. J Hazard Mater 101:315-322

Santos WNL, Cavalcante DD, Silva EGP, Virgens CF, Dias FS (2011) Biosorption of $\mathrm{Pb}$ (II) and $\mathrm{Cd}(\mathrm{II})$ ions by Agave sisalana (Sisal Fiber). Microchem J 97:269-273

Sasmaz A, Obek E (2009) The accumulation of arsenic, uranium, and boron in Lemna gibba L. exposed to secondary effluents. Ecol Eng 35(10): 1564-1567

Saygideger S, Gulnaz O, Salih E, Yucel N (2005) Adsorption of Cd (II), $\mathrm{Cu}$ (II) and $\mathrm{Ni}$ (II) ions by Lemna minor L.: effect of physicochemical environment. J Hazard Mater B126:96-104

Shukla SR, Pai RS (2005) Adsorption of Cu (II), Ni (II) and Zn (II) on modified jute fibres. Bioresour Technol 96:1430-1438

Singh A, Mehta SK, Gaur JP (2007) Removal of heavy metals from aqueous solution by common freshwater filamentous algae. World J Microbiol Biotechnol 23:1115-1120

Singh A, Kumar CS, Agarwal A (2011) Phytotoxicity of Cadmium and Lead in Hydrilla verticillata (L.F.). Royle J Phytol 3:1-4

Song HL, Liang L, Yan KY (2014) Removal of several metal ions from aqueous solution using powdered stem of Arundo donax $\mathrm{L}$. as a new biosorbent. Chem Eng Res Des (Article in Press). doi:10.1016/j.cherd.2014.04.027

Tasar S, Kaya F, Ozer A (2014) Biosorption of lead (II) ions from aqueous solution by peanut shells: equilibrium, thermodynamic and kinetic studies. J Environ Chem Eng 2:1018-1026

Tay CC, Liew HH, Yin CY, Abdul-Talib S, Surif S, Suhaimi AA, Yong SK (2011) Biosorption of cadmium ions using Pleurotus ostreatus: growth kinetics, isotherm study and biosorption mechanism. Korean J Chem Eng 28(3):825-830

Venny, Gan S, Ng HK (2012) Current status and prospects of Fenton oxidation for the decontamination of persistent organic pollutants (POPs) in soils. Chem Eng J 213:295-317

Verma A, Shalua Singha A, Bishnoia NR, Gupta A (2013) Biosorption of $\mathrm{Cu}$ (II) using free and immobilized biomass of Penicillium citrinum. Ecol Eng 61:486-490

Vijayaraghavan K, Palanivelu K, Velan M (2006) Biosorption of copper(II) and cobalt(II) from aqueous solutions by crab shell particles. Bioresour Technol 97:1411-1419

Yilmaz EI, Ensari NY (2005) Cadmium biosorption by Bacillus circulans strain EB1. World J Microbiol Biotechnol 21:777-779 
Yuan XZ, Meng YT, Zeng GM, Fang YY, Shi JG (2008) Evaluation of tea-derived biosurfactant on removing heavy metal ions from dilute wastewater by ion flotation. Colloid Surface A 317:256-261

Zan F, Huo S, Xi B, Zhao X (2012) Biosorption of $\mathrm{Cd}^{2+}$ and $\mathrm{Cu}^{2+}$ on immobilized Saccharomyces cerevisiae. Front Environ Sci Eng 6:51-58
Zhang M (2011) Adsorption study of $\mathrm{Pb}$ (II), Cu(II) and $\mathrm{Zn}$ (II) from simulated acid mine drainage using dairy manure compost. Chem Eng J 172:361-368 